\title{
Poznawanie siebie i poznawanie innego. Wobec inności literatury*
}

ABSTRACT. Łebkowska Anna, Poznawanie siebie i poznawanie innego. Wobec inności literatury [Learning about onself and learning about the other. In the fact of otherness of (in) literature]. "Przestrzenie Teorii" 5, Poznań 2005, Adam Mickiewicz University Press, pp. 9-26. ISBN 83232-1605-3. ISSN 1644-6763.

In my paper, I deal with the relationships between the present-day discourse in literature and literature itself: mainly in the aspect of the category of "otherness." Among many current understandings of that category, I analyse those for which literature is the sphere of what is distinct. That prospect also allows me to identify the experience of "otherness," being initiated owing to literature, and that only in the manner available to titerature. The category of "other-ness" is associated with the same meanings in which it appears in both present-day literature and cultural anthropology, consequently, it is identified with ethnic and gender distinctness, or the area of exclusion, or, just the opposite, the area of inclusion contrary to one's will, or alienation etc. In my paper, I concentrate on the methods of literary thematicality of learning about oneself and "the other" (I mainly limit myself to personal relationships, or novelistic "I" - "the other" relationships), which are present at various levels of present-day prose. I also take into account those literary strategies which serve the destabilization of both social and literary conventions and demonstrate "the otherness in the otherness" of literature. In conclusion, I point out dangerous trends which appear in literary studies: the one which leads either to excessive ideologization of literature or, vice versa, to excessive unification of the varieties of "otherness" presented in literature.

Zauważyłam, że Waud, z pochodzenia Norweg, zaczął regularnie uczęszczać na kurs o polskich prozaikach z przełomu stulecia dopiero od chwili pojawienia się na scenie Wacława Sieroszewskiego. Warszawski okres heroiczny pisarza [...] przyjmował obojętnie. Ożywił się i zaczął notować od czasu, kiedy nasz Sirko znalazł się na Syberii. „Gdzie ja mogę dostać tłumaczenie angielskie Jakutów" nastawał. Jakutów po angielsku nie mogłam mu dostarczyć, więc streścił sobie nowele o życiu podbiegunowym w tomach $\mathrm{Na}$ kresach lasów i $W$ matni i znikł. Bo przedmiotem głównym Wauda byla etnografia ${ }^{1}$.

Rzecz dzieje się pod koniec lat 60. na jednym z Uniwersytetów w Stanach Zjednoczonych. Panuje jeszcze strukturalizm, choć autorce cytowanych słów Jakobsonowska metoda analizy zdecydowanie nie odpowiada ${ }^{2}$.

* Jest to tekst referatu wygłoszonego podczas Zjazdu Polonistów „Polonistyka w przebudowie. Literaturoznawstwo - Wiedza o języku i kulturze - Edukacja”. 22-25 września 2004 r., Kraków.

${ }^{1}$ M. Kuncewiczowa, Natura, Warszawa 1975, s. 204.

2 Czemu dobitnie daje wyraz, pisząc o swoim spotkaniu ze strukturalizmem. Tamże, s. 198. 
Kim jest student? Wiemy o nim tylko tyle, że będąc Norwegiem, najprawdopodobniej traktował literaturę polską jako sferę egzotyczną: obcą ale pociągającą - być może nie tylko ze względu na konieczną do zaliczenia semestru liczbę punktów. Jednakże wykładów słuchał wyłącznie pod kątem własnych zaciekawień naukowych, trudno odgadnąć, czy - wobec niemożności lektury dzieła etnograficznego o Jakutach - potraktował streszczone nowele w funkcji prostodusznie poznawczej, czy - w co raczej należy wątpić - zainteresowany był literackimi opisami inności? A może intrygował go literacki wymiar dyskursu etnograficznego? Byłby więc nowoczesnym antropologiem na miarę Jamesa Clifforda? A może jeszcze inaczej: zafascynowany był polskim pisarzem na zesłaniu opisującym zwyczaje Jakutów, a więc innością w inności?

Kto opowiada? Powieściopisarka - cudzoziemka wykładająca historię literatury swego narodu, jednocześnie - przynajmniej na czas prowadzenia wykładów - badaczka literatury, która umieszcza tę anegdotę, traktując ją oczywiście $z$ przymrużeniem oka, w ramach spisywanych po latach wspomnień, w swej autonarracji świadoma zarówno własnej inności, wyobcowania siebie samej, jak i literatury: tej, którą tworzy, i także tej, którą wykłada. Dodać też należy - to pisarka nakierowana na odmiany inności (jeden z cyklów jej wykładów wygłaszanych w Chicago, Los Angeles i Berkeley poświęcony został kwestii żydowskiej w literaturze polskiej ${ }^{3}$ - a jednocześnie szczególnie wrażliwa na kwestie tożsamości kobiecej; powieściopisarka pisząca o sobie: „tylko w chwilach nieprzytomności bywam sobą, wszystkie inne postaci mojej osoby to simulacra"4, sama siebie nazywająca cudzoziemką i zarazem autorka Cudzoziemki oczywiście: Maria Kuncewiczowa.

Świadoma własnej inności, a także innością zafascynowana, opowiada o zderzeniu z cudzą odrębnością i cudzą fascynacją; umieszcza tę historyjkę w drugim tomie autobiograficznych Fantomów zatytułowanym Natura, włączając ją w ciąg zdarzeń niezgodnych z jej oczekiwaniem, acz - właśnie dlatego - wartych odnotowania.

I choć nie zamierzam poświęcić twórczości autorki Gaju oliwnego niniejszego artykułu, przypomniałam fragment $\mathrm{z}$ jej wspomnień $\mathrm{z}$ kilku powodów.

Po pierwsze, ze względu na zależności między literaturą a dyskursem o literaturze, które są dla mnie tu istotne, po drugie, ze względu na kwestię użycia literatury wyjątkowo mocno w przywołanym cytacie wyeksponowaną, po trzecie, ze względu na literacką - (acz w tym fragmencie kwestie te w mniejszym stopniu są obecne) - samoświadomość inności i zarazem traktowanie literatury jako źródła jej doświadczenia.

3 Tamże, s. 212.

${ }^{4}$ M. Kuncewiczowa, Fantomy, Warszawa 1975, s. 170. 
Gdyby wybierać spośród wielu odmian znaczeniowych „inności” obecnych w dyskursie współczesnej humanistyki, a jest ich aż nadto: od postmetafizycznej, etycznej, ontologicznej po antropologiczną i kulturowo-polityczną, a także, gdyby wybierać spośród wielu obiektów i sfer, umieszczanych przez tenże dyskurs w rejonach „inności”, zacząć należatoby od samej literatury. I to z dwóch względów. W pierwszym rzędzie ze względu na pojmowanie jej lektury jako kontaktu z tym, co inne. Otóż ostatnimi czasy - najdobitniej poglądy te wyrażone zostały przez myślicieli postdekonstrukcjonistycznych, zwłaszcza przez Derridę, Hillisa Millera, a także bardzo wyraziście przez Dereka Attridge'a. Nie będę tu szczegółowo odtwarzać ich koncepcji, gdyż w syntetyczny sposób bywały już one polskiemu czytelnikowi streszczane 5 . Powtórzę tylko, że lektura - wedlug tych założeń - to spotkanie $z$ innym, uobecnione w zdarzeniowości, kreatywności, inwencyjności. Przywołam jedynie wypowiedź H. Millera, który wprost mówi o „nieredukowalnej inności dzieła, inności nawet wobec kultury, która je w oczywisty sposób wygenerowała" i jeszcze dobitniej: „zastosowanie tłumaczenia wykorzenia dzieło, skaża je”.

Pomijam rolę i znaczenie takich poglądów dla dzisiejszej translatologii czy komparatystyki, zostawiam nieco z boku ich konsekwencje dla interpretacji literatury i etyki lektury, które wyraźnie dają o sobie znać w dzisiejszym namyśle nad literaturą i po części wiążą się, siłą rzeczy, także $\mathrm{z}$ moimi rozważaniami. Interesują mnie bowiem $\mathrm{w}$ tym momencie przede wszystkim relacje między dyskursem współczesnej antropologii i krytyki etycznej a samą literaturą.

Trzeba w tym miejscu przypomnieć, że pojmowanie literatury jako sfery inności, choć osadzone w odległych od siebie tradycjach myślowych - a szczególnie eksponowane ostatnimi czasy - wiąże się nie tylko z różnymi odmianami etyki czytania, której wymienieni uczeni są niewątpliwymi przedstawicielami, ale zarazem $\mathrm{z}$ działaniami - by tak rzec obronnymi. Obrony wymaga sama literatura. Oto - dla wyjaśnienia jeszcze jeden krótki cytat, znów z tekstu Hillisa Millera; mianowicie analizując przemiany $\mathrm{w}$ programach amerykańskich uniwersytetów, powiada on z wyraźnym ubolewaniem: „dla kulturowych studiów literatura nie jest już dłużej uprzywilejowanym wyrażeniem kultury [...] jest traktowana jako jeden $\mathrm{z}$ symptomów lub produktów kultury pośród innych

5 M.P. Markowski, O zwrocie etycznym $w$ badaniach literackich, „Pamiętnik Literacki" $2000, \mathrm{nr}$ 1. A. Skrendo niedawno nawiązywal do tego zagadnienia w artykule Dwa typy krytyki etycznej $i$ ich pogranicze, „Teksty Drugie” 2003, nr 2-3.

${ }^{6}$ J.H. Miller, Cultural Studies and Reading, w: Literary Theories. A Reader Guide, ed. by Julian Wolfreys, New York 1999, s. 609. 
[...] jest kategorią, która coraz bardziej zatraca to, co ją wyróżnia na nieograniczonym planie kulturowego dyskursu", staje się zatem - twierdzi dalej - taką samą praktyką kulturową jak styl ubierania czy sposób gotowania ${ }^{7}$. Przyznać tu trzeba, że obawy uczonego są uzasadnione8.

Rodzi się w sytuacji takiej kwestia natury podstawowej, mianowicie czy traktować literaturę jako nie wyróżniający się spośród innych, jeden z wielu sposobów mówienia o świecie, czy też pogląd taki odrzucić. Otóż bliskie jest mi takie podejście, które lączy się z pojmowaniem literatury jako dyskursu uprzywilejowanego, mimo faktu, że granice te są niestabilne i zatarte, podległe różnego rodzaju instytucjonalizacjom, historycznie zmienne, a ponadto wszelakie uwikłania kulturowe społeczne, estetyczne, polityczne, genderowe są tu niepodważalne. Owa wyjątkowość polega na tym, że literatura w sobie jedynie dostępny sposób otwiera szansę uchwycenia tych pograniczności, które w innych dyskursach są niewydobywalne. W swej transgresyjności umożliwia odsłonięcie procesu formowania tożsamości poprzez relacje między tym, co pozwala się scalić, a tym, co wymyka się procesowi scalania, między tym, co powtarzane jako konwencja, a tym, co podlega demistyfikacji, np. groteskowej hiperbolizacji. Dzięki projekcjom osobowości poprzez wielości masek, dzięki sposobom doświadczania świata poprzez projekcje fikcyjnych światów i w ich obrębie alternatywnych wersji zdarzeń czy poprzez kulturowe wzorce tożsamości kreowane jako bądź akceptowane, bądź jako narzucone - pozwala uchwycić to, co inaczej niepochwytne, to, co mieści się w kulturze oficjalnej i ją przekracza. Zrównanie literatury z innymi sposobami mówienia o świecie ( $\mathrm{z}$ dyskursem politycznym, psychologicznym itd.) niesie w sobie niebezpieczeństwo wyłącznie utylitarnego jej traktowania, z kolei czysta autonomizacja badań literackich okazuje się niewystarczająca. Ponadto zazwyczaj okazuje się złudną idealizacją.

Wydobywanie inności literatury równoznaczne jest zatem z niechęcią wobec poglądów znoszących jej uprzywilejowaną pozycję, a także $\mathrm{z}$ niechęcią wobec dwóch skrajności: sterylnej autonomii i łatwej służebności ${ }^{9}$. Dzialania obronne znajdują mocne wsparcie we współczesnej antropologii kulturowej, dla której literatura okazuje się najwłaściwszym sposobem mówienia o innym (perspektywa ta wiąże się w szczególności $\mathrm{z}$ wydobywaniem konstruktywistycznego, tekstowego, czy innymi słowy,

7 'Tamże, s. 605.

8 Zresztą w samych swych dzialaniach broniących literatury nie jest odosobniony. Szerzej problemami obrony (fikcji literackiej) zajmowałam się w ksiązce Między teoriamı a fikcja literackq, Kraków 2001.

${ }^{9} \mathrm{Na}$ niebezpieczeństwa tego rodzaju zwraca uwage np. D. Attridge, w artykule Literary Form and the Demands of Politics: Otherness in J.M. Coetzee's "Age of Iron, w: Aesthetics and Ideology, ed. by G. Levine, New Brunswick 1994. 
zapośredniczonego - wymiaru poznania). Wystarczy sięgnąć do dzieła Jamesa Clifforda czy Clifforda Geertza. Przy okazji warto też przypomnieć, że apologia literatury uwidacznia się u wielu współczesnych narratywistów: Taylora, Giddensa, Brunera, White'a analizujących opowiadanie świata siebie i innego.

Jeszcze inaczej przedstawiają się działania obronne z perspektywy teorii antropologii literackiej zaproponowanej przez Wolfganga Isera. Przypomnę tu: według uczonego (zmienna) funkcja literatury (zakorzeniona $w$ micie) polega na odsłanianiu białych miejsc; obszarów nieuchwytnych, nie pokrytych systemami wyjaśniającymi danej kultury ${ }^{10}$ i zarazem polega na przekraczaniu granic własnego ,ja”. Owo przekraczanie pojmowane jest jednak nie tyle w duchu Bataille'owskiej transgresji, ile jako fikcjonalizacja i zarazem inscenizacja umożliwiająca samopoznanie; zaś przekraczanie granic własnego ,ja" zagwarantować może jedynie triada wyobrażalnego, fikcyjnego i realnego. Triada ta - i tu zmierzamy do sedna - w pełni realizuje się jedynie na terenie literatury.

Tak więc, gdy podąża się śladem współczesnych jej admiratorów, siłą rzeczy przechodzi się od afirmacji literatury jako „innej” do takiej apologii literatury, której przyczyną jest uruchomione dzięki niej doświadczanie inności. Trudno bowiem nie zauważyć, że te dwa rodzaje admiracji współgrają ze sobą. Wystarczy przypomnieć (ograniczam się do najbardziej znanych przykładów) Derridowską lekturę Paula Celana ${ }^{11}$, Lévinasa czytającego tegoż Celana czy Prousta ${ }^{12}$; nie sposób nie przytoczyć poglądów Rorty'ego - jednakże nie tylko tych wyrażonych w znanym zdaniu: „Książki takie jak Middlemarch, Do latarni morskiej i Kolor purpury bardziej uświadomiły mężczyznom, co zrobili kobietom, aniżeli publikowane dane badań społecznych czy jakiekolwiek teorie feministyczne"13. Warte przypomnienia są zwłaszcza poglądy Rorty'ego czytającego Nabokova czy Borgesa, a więc najwyżej oceniającego literaturę określaną przez siebie mianem estetycznej czy samoświadomej, taką zatem, która przyczynia się do wciąż od nowa dokonywanego opisu własnej

${ }^{10}$ Choć Iser - co trzeba zaznaczyć - nie szafuje pojęciem „inności”. W dyskusji m.in. z Hillisem Millerem poświęconej temu zagadnieniu to właśnie on domaga się uściślenia zakresu znaczeniowego tego terminu. Według Isera literatura służy raczej przekraczaniu granic podmiotu czytającego, aniżeli otwarciu na inność. Z kolei można by się jednak zastanawiać, czy właśnie jego teoria nie jest tu najbardziej przekonywająca. (J.H. Miller, Humanistic Discourse and the Others, Roundtable Discussion „Surface, vol. VI. 103 http://www.pum.umontreal.ca/revues/surfaces/vol6/miller_1.html).

11 J. Derrida, Szibbolet, przeł. A. Dziadek, Bytom 2000.

${ }^{12}$ E. Lẻvin as, Imiona wiasne, przeł. J. Margański, Warszawa 2000.

${ }^{13}$ R. Rorty, Etyka zasad a etyka wrażliwości, przel. D. Abriszewska, „Teksty Drugie" 2002 , nr 1-2. 
podmiotowości, świata i innego ${ }^{14}$. I wreszcie - przypomnieć trzeba nazwisko myśliciela, którego w nawet najbardziej selektywnym wyliczeniu nie może zabraknąć, mianowicie Paula Ricoeura. Autor dzieła $O$ sobie samym jako innym precyzuje trzy odmiany inności15: (1) doświadczanie własnego ciała, (2) stosunek siebie do obcego, i (3) sumienie. Pisząc o drugiej odmianie, stwierdza, że „Lektura jako środowisko, w którym dochodzi do przeniesienia ze świata opowieści - a więc także świata literackich postaci - do świata czytelnika, stanowi wyróżnione miejsce i wyróżnioną więź wpływania na czytający podmiot” 16 i dalej: „Okazuje się więc, że wpływanie na tego-który-jest-sobą przez innego niż sam znajduje $w$ «fikcji» wyróżnione środowisko myślowych doświadczeń, którego nie mogą zaćmić "rzeczywiste" stosunki rozmowy i interakcji" 17.

Oczywiście nie twierdzę, że filozofowie ci mówią jednym głosem czy że takie same są ich zapatrywania na literaturę; czy wreszcie, że samo rozumienie głównej tu kategorii jest zbieżne. We współczesnych podejściach, gdy mowa o inności, sięga się zazwyczaj do tradycji Platońskiego Timajosa, a także do dwudziestowiecznej już filozofii dialogu, do sporu a raczej wzajemnej inspiracji, choć różnie ujawnionej - między Derridą a Lévinasem ${ }^{18}$. Nie sposób też nie zatrzymać się przy przełomie w badaniach literaturoznawczych i humanistycznych w ogólności, dla którego sprawą podstawową jest przekształcenie koncepcji podmiotu: a zwłaszcza skupienie się na relacjach między tym, co tożsame i zarazem inne, nie sposób też przynajmniej nie wspomnieć tu o zwrotach w stronę etniczności, płci kulturowej, mechanizmów władzy i polityki, czy wreszcie nie sposób nie przypomnieć - omawianego już wielokrotnie - zwrotu w stronę tego, co „inne”, a co zarazem wiąże się ze zmianą paradygmatu teoretycznoliterackiego.

Nie podlega zarazem kwestii, że współgranie współczesnej afirmacji literatury z refleksją nad „innym” łączy się z aporetycznością ${ }^{19}$ przedmiotu tejże refleksji. Niezależnie bowiem od tego, czy umieszcza się obecnie „inność" w sferze etyki i ontologii, czy w sferze polityki; czy pojmuje jako: to, co nie jest mną, jako to, co nie tożsame, jako inność i zarazem obcość, a także niezależnie od tego, czy inny pojmowany jest jako

14 Tenże, Przygodność, ironia, solidarność, przeł. W.J. Popowski, Warszawa 1996.

15 P. Ricoeur, O sobie samym jako innym, przeł. B. Chelstowski, Warszawa 2003, s. 529 .

16 Tamże, s. 548.

17 Tamże, s. 548.

${ }^{18}$ P. Pien iążek, U kresu obecności. Derrida a Levinas, w: Derridiana, wybór. B. Banasiak, Kraków 1994.

$10 \mathrm{O}$ aporetyczności m.in. Ricoeur, op. cit. 
ten, „którego odpowiedzialność ciąży na mnie”20, jako to, co poza normą; jako to, co we mnie, czy jako to, co na pograniczu podmiotu i przedmiotu, a więc zarazem jako to, co odrzucone, jako abject ${ }^{21}$ itd. - z reguły określa się inność poprzez negację - choć negację różnego rodzaju. Dzieje się tak bez względu na to, czy o inności piszą filozofowie, badacze literatury, antropologowie kultury, przedstawiciele krytyki etycznej, postkolonialnej czy genderowej.

Zbierając owe odmiany zaprzeczenia - ograniczam się do tego, co najbardziej zauważalne, choć zdaję sobie sprawę z tego, że ujęcie zbiorcze może prowadzić do nadmiernej homogenizacji - wymienić można wśród nich: inność pojmowaną jako to, co nie-tożsame, jako nie-ja, ale też to, co niereprezentowalne, niewysławialne, niedefiniowalne, nietematyzowalne, jako to, co nie da się skonceptualizować, co nieprzekładalne, gdyż zagrożone bądź poprzez zagarnięcie, bądź przez odrzucenie; tak więc inność może być dana jedynie poprzez niezawłaszczalność i niemożność odrzucenia, jako pragnienie tego, co nieobecne, jako to, co nieredukowalne (zwłaszcza w perspektywie społeczno-politycznej: inności jako obcości, wykluczenia). Sam termin określany bywa znów przez zaprzeczenie: jako nie-pojęcie, non concept, jak chce Hillis Miller ${ }^{22}$.

Owo nie-pojęcie występuje w wersjach: Inny, Inne, inni, inność, w pisowni: z małej czy z dużej litery w liczbie pojedynczej lub mnogiej. Dzieje się tak zazwyczaj $z$ powodu świadomości czających się tu niebezpieczeństw, takich jak popadnięcie w esencjalizm, uniwersalizm czy egzemplaryczność bądź zatarcie tego, co jednostkowe.

Nie pora, by mówić o - zauważonym już - nadmiernym wykorzystywaniu tej metakategorii (jak ją określa Ricoeur), czy o tym, jakie sytuacja ta niesie nieuchronne następstwa, ujawniając swą ciemną stronę ${ }^{23}$, najistotniejsza jest dla mnie rola, jaką przypisuje się literaturze; z traktowaniem jej jako dyskursu najwłaściwszego włącznie. Istotne jest dla mnie jej wyniesienie, wskazanie na jej swoistą niezbywalność właśnie uwidaczniające się w jej literackości.

20 E. Lẻvinas, Inaczej niż być lub ponad istotq, tłum. P. Mrówczyński, Warszawa 2000 , s. 154.

21 J. Kristeva, Powers of Horror. An Essay on Abjection, trans. L.S. Roudiez, New York 1982.

22 J.H. Miller, Humanistic Discours and the Other, op. cit., z. 27, s. 16.

${ }^{23} \mathrm{Na}$ kwestię swoistej koniunkturalności, marketingowego charakteru zwrotu w stronę „inności” zwracały uwagę np.: I. I wasiów, Cialo niechciane. Pogranicze identyfikacji seksualnej jako problem literatury i krytyki literackiej, w: Codzienne, przedmiotowe, cielesne, red. H. Gosk, Izabelin 2002 i A. Ubertow sk a, Paradoksy Innego, „Teksty Drugie" 2004, nr 1-2. 
Z jednej strony obserwuje się dziś zainteresowanie literackością (narracją, tropami, fikcjonalizacją itd.) dyskursów kultury, z drugiej zaś strony wyraźna staje się antropologizacja badań literackich. Spośród tych dwu - zachodzących na siebie - kręgów zajmować mnie będą miejsca wspólne obszaru wyrazistej samoświadomości literatury, szczególnie wyostrzonej ostatnimi czasy, i terenu dyskursu współcześnie pojętych badań literaturoznawczych. Ograniczam się tu jedynie do literackiej problematyzacji poznania siebie i innego, obecnej na różnych poziomach współczesnej prozy i przejawiającej się na wiele sposobów. A co istotne przyczyniającej się do efektu współbrzmienia, do podobnej tonacji słyszalnej zarówno w literaturze, jak i w dyskursach współczesnej humanistyki. Celem moim jest przyjrzeć się zwłaszcza relacjom między afirmującym dyskursem o literaturze a jej autorefleksyjnością.

Zamierzam zatrzymać się, w formie skrótowej, przy (1) międzyosobowych literackich relacjach między ,ja” a „innym”, szczególnie w duchu odpowiedzialności wobec innego, pojmowanego jako sfera nienaruszalna, jako tajemnica, jako to, co niewyrażalne; (2) skupić się na prozie fikcjonalnej ostatnich dziesięcioleci. Na boku zostawiam takie gatunki, jak: reportaże, listy, dzienniki, zwłaszcza listy z podróży czy nawet wspomnienia (mimo że właśnie fragment wspomnień zacytowałam na początku) i mimo że właśnie te gatunki są dziś szczególnie atrakcyjną „innością”. A także mimo tego że również one ujawniają niezbywalną literackość opowieści o innym. Ponadto zatrzymam się nie tyle przy figurach podmiotu i figurach „innego" (trudno zresztą byłoby przedstawić tu jakiś kompletny katalog), ile wyłącznie przy tym, co dzieje się na pograniczu: j a - o n - o n a, w dodatku w głównej mierze - co trzeba tu jasno powiedzieć - skoncentruję się na relacjach osobowych, rozumianych w sensie bliskim antropologii kulturowej. Kategorię „inności” łączę bowiem z tymi sferami, w jakich pojawia się ona we współczesnej literaturze, a więc $\mathrm{z}$ innością etniczną bądź genderową, z kwestią wykluczenia bądź - odwrotnie - włączenia wbrew własnej woli, wyobcowania, odmienności, skazania na milczenie, łączę z problemem dyskryminacji, związanej z przemocą, władzą, ale też z cierpieniem, chorobą, wiekiem.

Otóż relacja między poznaniem siebie i poznaniem drugiego człowieka zazwyczaj rozpięta jest między dwoma biegunami: między świadomością niepoznawalności, monadyczności a pragnieniem takiego odtwarzania w sobie innego, które nie narusza jego autonomii. Obydwa te bieguny łączą się bądź z zamierzonym minimalizmem, bądź z celowym nadmiarem literackości.

Opowiedzieć o innym, nie reifikując go, zachowując podmiotowy wymiar - oto jedno z zadań, które stawia przed sobą literatura współczesna i zarazem jedna $z$ jej w pełni uświadamianych aporii. Skupiam się zatem na poetykach inności zagadnienia te uwydatniających. 


\section{Oscylacja}

Narracja współczesna wyraźnie nastawiona jest na obrysowywanie cudzej świadomości, służy raczej gestowi zatrzymania aniżeli ingerencji. Elementem decydującym jest tu lęk przed redukcjonizmem. Dominuje świadomość określania własnej tożsamości poprzez inność zazwyczaj Z wyraźnym dlań respektem. $Z$ reguły wydobyty zostaje osobowy charakter relacji między ja i nie-ja (zazwyczaj jest to po prostu narracja 1-osobowa, czasem jednak może to być inscenizacja opowieści jednego $\mathrm{z}$ bohaterów narracji, jak np. u Tokarczuk). Odejście od narracji 3-osobowej, od klasycznych technik, rzadziej dziś stosowanych, jak np. mowa pozornie zależna, łączy się z niechęcią wobec domykających dookreśleń ${ }^{24}$. „Ja” podmiotowe - opowiadające i jednocześnie działające w świecie i świat ów w mniej lub bardziej demonstrowany sposób kreujące bądź - co najczęstsze - sylleptycznie ${ }^{25}$ uobecnione we wszystkich wymiarach, od jawnie tekstowego poczynając, a na autentyku kończąc - sprzyja problematyzacji różnicy i identyfikacji. Opowiadający i opowiadany nieustannie balansują tu między fikcją i metafikcją i zarazem między pragnieniem poznania a jego niemożnością, zaś obnażanie literackości sytuację tę ma wydobywać.

Zabiegi oparte na odmianach oscylacji widoczne sa zwłaszcza w takich narracjach, które powstały jako opowieść o drugiej osobie (jako opowiadanie siebie poprzez cudzy życiorys). Tu właśnie pogranicza między „ja” a „innym” kumulują się w wyjątkowym nasileniu. Tu także zazwyczaj ujawniona zostaje opalizacja między narracją fikcyjną i niefikcyjną ${ }^{26}$. Wyraźnie tego typu pogranicza widoczne są w tych utworach, które nawiązują do form biograficznych (Bohin Konwickiego, Bialy kamień Boleckiej, opowiadania Grudzińskiego czy Filipak). Podmiot opowiadający przyjmuje rolę detektywa, biografa-świadka, śledczego odtwarzającego swoją i cudzą przeszłość itd. Akcenty rozkładają się tu: od próby scalenia opowieści o cudzym życiu do biografii odpryskowej, od osobności i obcości do prób identyfikacji z zatratą tożsamości opowiadającego włącznie.

W innych przypadkach narracja 1-osobowa łączy się często z 3-osobową - na zasadzie gry zaimkami (Liskowacki, Filipiak). Krótko mówiąc:

${ }^{24}$ Co oczywiście nie oznacza: całkowicie nieobecnych. Formy te pojawiają się np. u Chwina, Odojewskiego i innych.

${ }^{25}$ Wykorzystuję tu termin z poetyki w znaczeniu, jakie mu nadał R. Nycz w odniesieniu do podmiotu w: Język modernizmu, Wrocław 1997.

${ }^{26} \mathrm{Nie}$ tylko bowiem podmiot opowiadający usytuowany bywa na pograniczu fikcji i autentyku (w sposób typowy dla współczesnych - i już wielokrotnie omawianych odmian autobiografizmu), ale także osoba, o której opowiada, na pograniczach tych bywa przedstawiana. 
dzieje się tak, jak gdyby dopiero odsłonięty wymiar kreacji czy przejaskrawione ujawnienie literackości dawały licencję na opowiadanie wnętrza postaci. Tym samym potencjal poznawczy fikcji i moce sensotwórcze narracji są tu nieustannie poddawane testom sprawdzającym.

Oscylacje tego rodzaju współgrają $\mathrm{z}$ mediatyzacjami odmian proliferatio i dyslokacjami.

\section{Mediatyzacje}

Wydobywanie konstruktowego charakteru opowieści o „innym”, osłaniającego pęknięcie między pragnieniem poznania a jego niemożliwością przejawia się w rozbudowanej sferze zapośredniczen. Uwidacznia się ona poprzez mnożenie wizerunków (przedstawień twarzy na fotografiach, portretach) poprzez opisy ekfrastyczne, ale też poprzez obrazy i fotografie jako przedmioty, listy, również w funkcji gatunku, a także przedmiotu pośredniczącego; poprzez sposoby przedstawiania przeszłości (Chwin, Filipiak, Libera), poprzez przymierzanie opowieści (Bieńczyk w Twor$k a c h)$, stylizacje, przykładanie klisz kulturowych, ale téz poprzez naśladowanie sposobów zachowań, noszenie podobnych ubran (Filipiak, Tokarczuk). I wreszcie poprzez próby mówienia cudzym językiem (np. Kruszyński). Sfery te uwidaczniają się też w pograniczu między wnętrzem i zewnętrzem pojmowanym bądź jako wnętrze psychiczne i otoczenie zewnętrzne (najbliżej tu zatem do persony - maski w sensie Jungowskim), bądź na zasadzie granicy cielesnej.

Spośród wielu przykładów najłatwiej przywołać mechanizmy mediacji w tych opowieściach, w których inny jest obiektem bądź admiracji, bądź przynajmniej - w swojej tajemniczości - fascynacji. Wzorcem może być na przykład bildungs roman opowiedziana w retrospektywie. Sztandarowymi przykładami (i też bodaj najczęściej analizowanymi) są powieści Weiser Dawidek Pawła Huellego i Hanemann Chwina, wymienić tu też można np. powieści i opowiadania Kruszyńskiego czy Liskowackiego.

\section{Proliferatio}

Mediatyzacja pełni zazwyczaj funkcję sfery niezbędnej, jedynie możliwej formy relacji z innym, łączy się zazwyczaj z mnożeniem działań służących poznaniu. Działania te przejawiają się zarówno poprzez nadmiar uporządkowań naddanych (Bieńczyk Tworki, Filipiak), jak i poprzez nakładanie kostiumów mitologizacyjnych (Tokarczuk, Odojewski Oksana), czy nawarstwianie perspektyw widzenia świata m.in. poprzez 
upersonifikowane przedmioty; ale też poprzez mnożenie perspektyw dziecka i dorosłego, widoczne zwłaszcza w narracjach wspomnieniowych (,ja” z przeszłości i z teraźniejszości: u Chwina, Herlinga-Grudzińskiego, Huellego, Filipiak, Tokarczuk - wymieniam, nie bacząc na różnice pokoleniowe) ${ }^{27}$. Zasada proliferatio ujawnia się także $w$ rozbudowanym i ujawnionym mnożeniu fabuł i poziomów metafikcji. Tu szczególną rolę odgrywa nawarstwianie wymiarów: fikcji mimetycznej i jawnej tekstowości (Kruszyński, Filipiak); celowe eksponowanie niestabilności ontologicznej, nakładanie form gatunkowych itd.

Konstrukcjonizm poznania może przybrać formę ujawnionego światotwórstwa, ustawicznego obnażania wymiaru kreacyjnego (np. Gra na wielu bębenkach Tokarczuk; Rosyjska księżniczka Filipiak), gdy odsłonięciu ulega fikcjonalny charakter mocy poznawczych. Zabiegi tego rodzaju widoczne są w różnych odmianach: bądź w opowieści nakierowanej na innego (np. Liskowacki, Huelle, Chwin, Tokarczuk), bądź w opowieściach prowadzonych $z$ jego perspektywy (w powieściach Filipiak, Kruszyńskiego, Hollender, Zyty Rudzkiej, Evy Hofman, Grynberga i in.), bądź gdy inność staje się kategorią zagarniającą każdy z podmiotów opowieści (Tokarczuk Gra na wielu bębenkach).

Przede wszystkim proliferatio ujawnia się także w powieleniu inności w wielu postaciach. Otóż przywykliśmy już do zwielokrotnienia narracyjnego ,ja" - tak dzieje się chociażby we wcześniejszych powieściach Konwickiego, np. w Nic albo nic czy w Senniku współczesnym (chociażby dzięki grze zaimkami osobowymi, dzięki powtórzeniu własnych cech narratora $w$ innych postaciach). Tymczasem $w$ dzisiejszych powieściach pomnożeniu ulega nie tylko ,ja”; analogicznym zabiegom poddawana jest osoba „innego". Oto najbardziej sztandarowe przykłady: w powieści Huellego Weiser Dawidek od pewnego momentu prawie wszyscy bohaterowie stają się znakami inności, poprzez zabiegi stylizacyjne, mitologizacyjne (także w swoim podobieństwie do głównego bohatera). W Hanemannie Chwina granica między tożsamością i nietożsamością wspólnotową staje się znakiem każdej postaci (podobnie u Tokarczuk czy Kruszyńskiego). Z kolei u Konwickiego w jego późniejszych powieściach - jak choćby w Czytadle - pojawiają się także wyraźne sygnały, by tak rzec, słabej tożsamości postaci (np. postaci męskich identyfikujących się z kliszami społecznymi, z ikonami męskości).

Ponadto niezwykle chętnie wykorzystywane są gatunki (i ich odmiany) wydobywające sytuacje poznania, jak np. - wspomniana już - bil-

27 Odmiany inności pojawiające się w utworach tych autorów doczekały się juz licznych cennych interpretacji, m.in. P. Czaplińskiego, M. Dąbrowskiego (w książce Swój) obcy/inny, Izabelin 2001 - w całości poświęconej tym kwestiom) A. Fiuta, H. Gosk, J. Jarzębskiego i innych. 
dungsroman, powieść inicjacyjna, detektywistyczna, strategia reportażu itp. Zdarzenia oparte na schemacie poszukiwania-poznania opowiedziane w spójny sposób przybrać mogą formę narracji skrajnie fragmentarycznej. Wszystkie one zazwyczaj skrywają w sobie sferę przemilczeń; ujawniają fakt, że sfera dostępu do innego, jeśli w ogóle jest osiągalna, to niekoniecznie w sposób możliwy do wyrażenia.

\section{"Inny - inny" - dyslokacja}

Jak widać, relacja ,ja - inny" często ulega zatarciu. Jednakże samo określanie siebie wobec inności może przybrać formę zakłócenia poprzez wprowadzenie figury innego - innego. Jak np. w powieści Kruszyńskiego Schwedenkrauter. Tu sytuacja emigranta opisywana jest poprzez odmiany narracji pierwszoosobowej, która nieustannie balansuje między „ja”, a więc wyrazem jednostkowości, i „my”: wyrazem zbiorowości; we wszystkich tych odmianach przeciwstawiona narracyjnemu „wy". Ukazana głównie poprzez mnożenie zapośredniczeń, tworzy układ właściwie spójny, z wyraźnym podziałem ról: dokładnie bowiem wiadomo, kto jest u siebie, a kto jest obcy. Jednakże niejako marginesowo pojawiają się „inni - inni”, np. poznany w czasie wyjazdu sąsiad z pokoju - odmienny w swoim homoseksualizmie. Przypadkowy znajomy narusza stabilny układ - sytuacja inności ulega przemieszczeniu, zaś narracja prowadzona $\mathrm{w}$ dalszym ciągu $\mathrm{z}$ pozycji tego samego wyobcowanego emigranta w pewnym momencie staje się opowieścią o innym rodzaju wyobcowania.

Dyslokacje mogą jednak przybrać też inny charakter. Jako przykład figury „innego - innego” i zarazem kumulacji inności może posłużyć postać Adama ${ }^{28}$ - znów z powieści Chwina Hanemann - chłopca o nieznanej i tajemniczej przeszłości, niemowy, który posiada jedyny w swoim rodzaju talent pantomimicznego naśladownictwa. Pantomima ta staje się figurą wszechmożliwej opowieści (język gestów opanowują wszystkie główne postaci). Brak własnego głosu u Adama łączy się tu z możliwością naśladowania pozostałych bohaterów powieści, $z$ ich odtworzeniem i zarazem kreacją: a także $z$ odsłonięciem ich inności. Narracja cielesna, pismo ciała, które do perfekcji opanował Adam, służy kopiowaniu innych ponad podziałami językowymi. Staje się jednocześnie i projekcją inności, i jej kopiowaniem, a zarazem figurą nieustannej - prześmiewczej - identyfikacji.

${ }^{28}$ Postacią tą zajmowali się już m.in. P. Czapliński, J. Jarzębski, K. Uniłowski. Warto przypomnieć, że J. Jarzębski w swej książce nazwał tę postać kwintesencją Inności, w: Apetyt na przemianę, Kraków 1997, s. 114. 
Dzięki pantomimie dokonuje się przemieszczenie relacji między tożsamym i innym. Naśladowanie i kreacja bowiem funkcjonują tu jako figura powtórzenia i re-prezentacji (uobecniania, a tym samym dyslokacji między tożsamym a nie - tym - samym) i zarazem - przynajmniej na krótko - ujawnia się jako figura rozładowania napięcia, uwolnienia inności: „(I chwilami już nie bardzo wiedziałem, kto jest prawdziwszy: czy my, żywi, cieleśni, [...] czy ci tutaj - wyłowieni palcami ze słonecznego światła, sprowadzeni do jednego gestu, do jednego grymasu, który ich na moment obdarzał chwiejnym istnieniem, a potem z lekką, obojętną radością rozwiewał w nicość"29. Odmienność Adama prowadzi do zjednoczenia głównych postaci powieści, przyczynia się té̇ do związku między Hanemannem a Hanką, do chwilowej wspólnoty, także ponad podziałami językowymi. Brak zaufania do języka mówionego jest tu zresztą często ujawniany. Jak się okazuje, wspólnoty w swojej pełni niemożliwej i krótkotrwałej. Przypomnijmy: Adam - wraz z Hanką i Hanemannem - wobec sytuacji zagrożenia musi potajemnie opuścić miasto.

Zazwyczaj w dzisiejszej literaturze wymiar epistemologiczny przecina się z etycznym. „Ja” rozproszone, odpryskowe może dążyć do scalenia w autonarracji, ale opierając się na „inności” - równie niepochwytnej. Droga wiedzie od poznania ,innego" do samopoznania; od nakładania wizerunków ,ja" na „innych” do odtwarzania wielości w sobie. A zatem literatura daje szansę przemieszczenia stabilnych konstruktów, odsłaniając możliwość przeczucia epifanii.

Zatrzymałam się przy prozie współczesnej, zwłaszcza przy sygnałach samoświadomości - mniej lub bardziej widocznych - nie twierdzę jednak, że zwrot w stronę „innego" - by posłużyć się nadużywanym już określeniem - nie był obecny wcześniej czy że nie można mówić o analogicznych relacjach w przypadku prozy tzw. niefikcjonalnej. Choć - niewątpliwie kwestie etyczne, antropologiczne, ontologiczne i estetyczne są tu właśnie szczególnie mocno ze sobą splecione. Co istotne, samoświadomość literacka skupiona na rozdźwięku między niepoznawalnością a pragnieniem poznania, między respektem dla autonomii a problemem jej naruszalności współgra niejako harmonijnie z głosami afirmującymi literaturę.

W sytuacji takiej trudno jednak nie zadać pytania: czy rzeczywiście wystarczy mówić tu jedynie o harmonii i symbiozie?

Można by bowiem nabrać przeświadczenia, że literatura i poglądy na jej rolę tworzą splot gładkiej tkaniny lub że łączą się w pełnej i niczym nie zakłóconej bezkonfliktowej atmosferze. Jednakże przeświadczenie

29 S. Chwin, Hanemann, Gdańsk 1997, s. 229-230. 
takie nie byłoby do końca słuszne. Problem polega bowiem na tym, że literatura może przekraczać swe granice w inny jeszcze sposób, mianowicie ujawniając własną „inność w inności”. Dla przykładu, ukazane przed chwilą sposoby problematyzacji poznania „innego” moga m.in. sprzyjać zakłóceniu kulturowych wzorców tożsamości, także tych, które charakteryzują się bodaj najmocniejszą stabilnością, nadbudowane są bowiem nad podziałem płciowym, tworząc kulturowy wzorzec męski i kobiecy30.

Zabiegi te mogą zarazem otwierać możliwość innego jeszcze rodzaju, możliwość nie do pominięcia: mianowicie usłyszenia głosu inaczej ustawionego. Na przykład takiego, który staje się słyszalny nie tyle, czy przynajmniej nie wyłącznie, poprzez nagłaśnianie modelu opozycyjnego wobec już istniejących $\mathrm{w}$ literaturze, ile - i tu odchodzę od metafor dźwiękowych na rzecz motorycznych - poprzez strategię "delikatnego odchylenia" ${ }^{1}$, choć ta delikatność może przybrać też formy bardziej zdecydowane, a więc dzięki zabiegom, które łączą się z istniejącymi już sposobami pisania, jednocześnie je przemieszczając.

Mam tu na myśli zwłaszcza taką odmianę literatury, która często funkcjonuje jako „inna - inna”, która chce funkcjonować w istniejącym systemie literackim, jednocześnie system ten przekraczając - na zasadzie nierozstrzygalności - wpisując się w istniejące juź sposoby stawiania oporu temu, co nazwijmy ogólnie: oficjalne, ale zarazem od nich tez się różniąc. Jak nietrudno skonstatować, zmierzam do tego typu literatury, którego inność łączy się z programową własną niedefimiowalnością i współgra z uchylaniem się wszelkim jednoznacznym domykającym dookreśleniom. Takiego zatem typu, który nosi nazwę écriture féminine ${ }^{32}-$ przy wszystkich zróżnicowaniach, jakie ta odmiana pisarstwa w sobie niesie (od jawnej manifestacji po obecność skrytą). Wspomniana już nierozstrzygalność współgra tu z zatarciem relacji między podmiotem a przedmiotem, między wnętrzem a zewnętrzem, między tym, co kulturowe, a tym, co cielesne ${ }^{33}$.

${ }^{30}$ Niczym w opowiadaniu Powrót Nataszy Goerke rozpoczynającym się od słów „Wiedziałem, że znów jestem kobietą"; zob. N. Goerke, Fractale, Poznań 1994, s. 122.

${ }^{31}$ Termin P.M. Spack w: E. Show alter, Krytyka feministyczna na bezdrozach, thum. I. Kalinowska-Blacwood, w: Wspólczesna teoria badań literackich za granica, red. H. Markiewicz, TIV, Kraków 1996.

${ }^{32}$ Termin H. Cixous.

${ }^{33}$ Nie tyle jednak chodzi tu o taką odmianę, którą Ricoeur w swojej typologii inności określił jako „doświadczenie własnego ciała [...] jako pośrednika między tym-który-jestsobą a światem" (P. Ricoeur, op. cit., s. 529), ile raczej o pogranicza między podmiotem i przedmiotem uobecnione $w$ tym, co odrzucone, nieakceptowane, niechciane na przykład społecznie, chodzi zatem o inność pojmowaną jako zakłócenie identyczności, systemu, porządku. 
Tak więc odbyliśmy drogę od literatury jako ,innej” do literatury jako „innej - innej”. Spośród wielu odmian tego pisarstwa w grę wchodziłyby także te odmiany, które problematyzują kwestię inności w taki sposób, że destabilizują konwencje zarazem społeczne i literackie, w dodatku naruszając to, co zdawałoby się najmniej naruszalne (nawet pomimo faktu, iż literatura zdążyła nas już przyzwyczaić do tego, że obszarów nienaruszalnych praktycznie w niej nie ma). Przykładem może być książka zatytułowana Blony umyslu Jolanty Brach-Czainy, gdzie miast spodziewanego imienia i nazwiska znajdujemy określenie: Jolanta córka Ireny wnuczka Bronisławy prawnuczka Ludwiki. Na boku zostawiam fakt, że mamy tu do czynienia ze zbiorem esejów, a nie np. z metafikcyjną powieścią.

Tu - nie tylko strategia odchylenia przenosi się na teren paratekstu, a działania na tym terenie zazwyczaj odbierane są jako szczególnie zakłócające powszechne przyzwyczajenia, ale tym samym niezwykle dobitnie podsuwa się czytelnikowi samoświadomy charakter esejów. Oczywiście - można podać przykłady zakłóceń z pozoru podobnych, jak chociażby podpis Slawomira Shuty, tak właśnie sygnującego swoje utwory. W imieniu własnym: Sławomir Shuty wyraźna jest tendencja do podważania istniejących konwencji - zwłaszcza poprzez pisownię, jednak nietrudno zauważyć stylizujące nawiązania do sygnatur $w$ historii kultury znanych z dawien dawna, ale też równie nietrudno dojrzeć tu ukłon w stronę futurystycznej ortografii czy do podpisów-pseudonimów internautów, a wszystko to $\mathrm{w}$ aurze zaznaczenia (nieco prześmiewczego) sytuacji społeczno-urbanistycznej ${ }^{34}$. Z kolei imię własne autorki Blon umystu jest wyraźnym gestem odrzucenia konwencji patriarchalnej, w istocie odbierającej kobiecie prawo do własnego nazwiska (zawsze należy ono do ojca lub męża). Nie jest to jednak odrzucenie całkowite - na ostatniej stronie okładki zostaje ujawnione zarówno nazwisko autorki, jak i przyczyny jej postępowania. I choć łatwo wykazać tu podobieństwa: np. obydwa imiona własne naruszają konwencje literackie, można też dostrzec różnice. Umieszczenie w miejscu, gdzie czytelnik spodziewa się imienia i nazwiska autora, słów: Jolanta córka Ireny wnuczka Bronisławy prawnuczka Ludwiki służy nie tylko grze $z$ istniejącą już tradycją literacką, a chwyt ten ewidentnie dominuje w pseudonimie autora Zwatu, ile do pewnego stopnia także służąc tej grze, zarazem przyczynia się do zdecydowanego jej przekroczenia. Wyjaśnienie z ostatniej strony okładki, które brzmi: „Jolanta Brach-Czaina nie ukrywa się pod pseudonimem. To prawda, że jest córką Ireny, wnuczką Bronisławy, prawnuczką Ludwi-

34 Sam autor podsuwa zresztą genezę swego pseudonimu: jako błędne zapisanie przez siostrę kolegi - informacji telefonicznej. Określenie „z Huty” zostało potraktowane jako nazwisko i tak właśnie zanotowane. http://miasta:gazeta.pl/kraków/1.35802,2280890.html 
ki. Te fakty ukrywa jednak cywilizacja, skazująca międzypokoleniowe więzi matrylinearne na zapomnienie"35 - stwarza inną sytuację. Rzecz polega bowiem na wpisywaniu się w strategie zaklócające przyzwyczajenia czytelnika $\mathrm{i}$ jednoczesnym ich wyjaśnianiu. Postawa feministyczna autorki zostaje tu jednoznacznie ujawniona, równie jednoznacznie ujęte są kwestie narzucanego przez system patriarchalny językowego określania własnej tożsamości - ukazanej tu w dwojakiej możliwości: w sferze niezależności i jednoczesnej nieuniknionej zależności. Bycie w systemie i bycie poza nim to - jak wiadomo - jedna ze strategii pisarstwa feministycznego.

Przykłady powyższe pojawiły się nie bez powodu, interesuje mnie przecież pytanie o harmonię czy konflikt między samoświadomą literaturą a pozycją badacza. Otwiera się zatem problem następujący. Otóż można by ograniczyć się jedynie do ogólnych rozważań na temat samej zasady tworzenia mechanizmów literackiego oporu i demonstrowania „,inności”. Można by powiedzieć, że tego typu przekroczenie granic i taki sposób stawiania oporu temu, co centralne, oficjalne, zgodne z normą, odnaleźć można w wielu typach literatury. Można by więc, podążając tym stylem myślenia - przypatrując się tej deklarowanej inności w inności - włączyć książkę Brach-Czainy w literaturę w ogólności swojej pojmowaną jako ta, która służyć ma opisywaniu siebie, świata i innego wciąż od nowa, w sposób niedomknięty, wolny od klisz itd., która na różne sposoby eksponuje własną samoświadomość itp. A zatem taką, która łączy się - znów powtórzę - z tym, co wspólne dla dzisiejszej literatury, widoczne zwłaszcza w jej wymiarze jawnie samoświadomym, a co ostatnimi czasy bywa najwyżej cenione.

Zarazem jednak rodzi się wówczas niebezpieczeństwo, z którego dzisiejsi badacze i badaczki literatury zdają sobie sprawę, takie mianowicie, że owa deklarowana inność $w$ inności ulegnie rozmyciu i unifikacji, zatracając to, co było jej celem. A wśród tych celów wymienić trzeba żądania stawiane odbiorcom tekstu, między innymi właśnie żądanie nie tylko rozpoznania owego „odchylenia", ale zarazem wymaganie, by ujawnić własne nastawienie badawcze.

A zatem, a jest to sprawa, której trudno tu nie poruszyć - zwłaszcza że Zjazd Polonistów poświęcony jest m.in. przedmiotom i celom polonistyki, a więc także celom literaturoznawcy: mianowicie: czy badacz winien wychodzić naprzeciw poszczególnym literackim innościom, skupiać się głównie na tym, by dostrzegać, wydobywać ich odmiany, czy raczej czytać $w$ sposób uogólniający, ale tym samym unifikując, ujednolicając przedmiot badań.

$35 \mathrm{~J}$. Brach-Czaina, Blony umyslu, Warszawa 2003. 
Tym samym powraca problem - przypomnianych na początku wystąpienia, opisywanych przez Kuncewiczową - nieporozumień. Rodzi się bowiem pytanie o sytuację badacza, pytanie o niebezpieczeństwo redukcjonizmu literatury czy - mówiąc inaczej - niestosownego jej użycia, wyłaniające się w różnych swych postaciach. Wśród nich pojawia się pułapka, która - jak można by sądzić - zagrażała właśnie studentowi Kuncewiczowej. Mianowicie: odsunięcie $\mathrm{z}$ pola widzenia literackości: na przykład fikcjonalnego statusu świata przedstawionego, figuratywności itp. na rzecz socjologicznych analiz „inności” Nie muszę chyba dopowiadać, że taka postawa jest mi z gruntu obca.

Wydobywam kwestie niebezpieczeństw, ponieważ ostatnimi czasy dają się słyszeć głosy wskazujące na zagrożenia, które towarzyszyć by miały badaczkom i badaczom, zagrożenia łączące się z dwoma rolami: albo niwelatora inności w inności, a więc unifikatora, albo wsłuchującego się $\mathrm{w}$ odmiany inności. Tu $\mathrm{z}$ kolei pojawia się problem przesadnej instrumentalizacji literatury, jej lektury nadmiernie zideologizowanej (zarzuty te dotyczą m.in. studiów genderowych). Pułapek - dodajmy - jest zresztą więcej ${ }^{36}$.

Najbardziej sensowne wydaje mi się w takiej sytuacji przyjęcie perspektywy takiej, która pozwala dostrzegać ogólne zjawiska literackie i zarazem uchwycić tendencje różnicujące, nie doprowadzając do ich unifikacji i braku szacunku dla specyfiki ich głosu. Choć zdaję sobie sprawę $z$ tego, że takie rozwiązanie - zdawałoby się oczywiste i nawet banalne w swoim wymiarze zdroworozsądkowym może spotkać się z zarzutami zarówno ze strony przedstawicieli perspektywy uogólniającej, jak i zwolenników respektowania inności w inności ${ }^{37}$.

Myślę tu bowiem o takim rodzaju postawy badawczej, która daje szansę na uniknięcie lektury z jednej strony przesadnie zideologizowanej czy instrumentalizującej, $\mathrm{z}$ drugiej nadmiernie ujednolicającej i unifikującej odmiany inności. Dla takiego rodzaju odbioru pomocna może być kategoria wrażliwości. Można mianowicie kategorię tę potraktować jako rodzaj odbioru nakierowanego na przejawy represjonowania inności i jednocześnie jako przejaw wpisanego w tekst literacki oporu wobec tego, co narzucone, można ją też pojmować jako taki sposób obcowania z literaturą, który nie dopuszcza do skrajnie instrumentalizującej lektury. Tak więc lektura ta łączyłaby się z takim obcowaniem z tekstem, które zarówno ujmuje literaturę jako przejaw pewnych zjawisk ogólnych,

${ }^{30} \mathrm{~Np}$. pojawia się niebezpieczeństwo, już wspomniane - mianowicie rola koniunkturalisty, w inności dostrzegającego dobry chwyt marketingowy.

${ }^{37}$ Gwoli wyjaśnienia muszę tu dodać, że tego typu polaryzacje szczególnie wyraźnie dają o sobie znać w tekstach badawczych dotyczaccych problematyki genderowej - choć nie tylko. 
jak i cechuje się wyczuleniem na to, co jednostkowe; jednakże przede wszystkim wiązałaby się zarazem $z$ przekonaniem, że to właśnie literatura w sposób jej jedynie dostępny może kulturowe konstrukty wydobywać i uchylać. Lektura ta współgra $z$ uwrażliwieniem na to, co dane bezpośrednio, i zarazem na to, co nieobecne, to, co na granicy opowiadalności, co ukryte i wymagające uobecnienia. Co najistotniejsze: lektura ta możliwa jest jedynie dzięki literaturze i tym samym uzależniona jest od literackości danego tekstu.

Jedno w tym wszystkim nie ulega wątpliwości, literatura, jak zwykle, nie daje się zamknąc $w$ działaniach obłaskawiających, ciągle przekracza własne granice - i jak zwykle - tworzy dla nas, badaczy, istotne wyzwanie. 